\title{
Abbâsî İdarî Tarihi Açısından Önemli Bir Kaynak: Dîvânü'l-inşâ Reisi Emînüddevle İbnü'l-Mûsalâyâa (ö. 497/1104) Tarafından Kaleme Alınan Resmî ve Şahsî Mektuplar*
}

\author{
Halil İbrahim Hançabay**
}

Hıristiyan asıllı dedelerinden birine nispetle daha çok İbnü'l-Mûsalâyâ olarak tanınan Ebû Sa‘d Alâ b. Hasan b. Vehb 412 (1066) yılında Bağdat'ın Kerh bölgesinde doğmuştur. Babası Hasan b. Vehb Abbâsî Halifesi Kāim-Biemrillâh (422-467 / 1031-1075) döneminde Dîvânü'l-inşẩda kâtip olarak çalışmıştır. Babasının vefatından kısa bir süre sonra (432/1040) aynı divanda kâtiplik yapmaya başlayan İbnü'lMûsalâyâ daha sonra Dîvânü'l-inşâ reisliğine atanmıştır. Bu görevini devam ettirirken Muktedî-Biemrillâh (467-487 / 1075-1094) ve Müstazhir-Billâh (487-512 / 1094-1118) dönemlerinde üç defa nâibülvezir olarak görevlendirilmiş ve 497 (1104) yılında Bağdat'ta vefat etmiştir. Abbâsî bürokrasisinin çeşitli kademelerinde elli yılı aşkın bir süre görev yapan İbnü’l-Mûsalâyầnın kaleme aldığı resmî ve şahsî mektuplardan altmış altı tanesi zamanımıza kadar ulaşmıştır. Bu mektupların büyük bir kısmı (yaklaşık kırk tanesi) Tuğrul Bey, Alparslan, Melikşah, Amîdülmülk el-Kündürî ve Nizâmülmülk gibi Büyük Selçuklu sultanları ve vezirlerine hitaben yazıldığı için Abbâsî-Selçuklu ilişkileri açısından birinci elden kaynak özelliği taşımaktadır. Diğer taraftan Fahrüddevle ve İbn Dârest'in vezirliğe, bir kişinin de kādılkudatllğa tayin edildiğine dair halife tarafından çıkarılan tevkī metinlerini ihtiva etmesi ve bazı divanlarla ilgili önemli ipuçları sunması bu mektupların geç dönem Abbâsî idarî tarihî açısından da kıymetli birer kaynak olduğunu göstermektedir. Bu çalışmada önce İbnü'l-Mûsalâyânın hayatı üzerinde durulacak, ardından söz konusu mektuplardan hareketle Büveyhîler'den Selçuklular’a geçiş sürecinde Abbâsî idarî tarihine dair bazı bilgiler verilecektir.

Anahtar Kelimeler: Abbâsîler, Selçuklular, İbnü'l-Mûsalâyâ, vezirlik, kādılkudatlık, divan.

* XVIII. Türk Tarih Kongresi’nde "Abbâsî İdarî Tarihi Açısından Önemli Bir Kaynak: Emînüddevle İbnü’l-Muvsalâyâ (ö. 499/1106) ve Risâleleri” adıyla sunulan tebliğin gözden geçirilmiș halidir.

** Dr., İstanbul Üniversitesi İlahiyat Fakültesi, ORCID oooo-ooo2-0387-0824

halilhancabay@gmail.com 


\section{Giriş}

İslam tarihinin erken dönemlerinden itibaren başta divan kâtipleri olmak üzere devletin çeşitli kademelerinde çalışan veya halife ve vezir gibi devletin en üst makamında bulunan kimselerle şahsî dostluklar kuran kişilerin yazdıkları eserler siyasî ve idarî tarih açısından birinci elden kaynak özelliği taşımaktadır. Emevî Halifesi II. Mervân’ın (127-132 / 744-750) kâtibi Abdülhamîd el-Kâtib’in (ö. 132/750) büyük bir kısmı zamanımıza ulaşmayan mektupları, yine Abdülhamîd el-Kâtib'in yakın dostu ve Emevîler'den Abbâsîler'e geçiş sürecinin tanı̆̆ İbnü’l-Mukaffâ'in (ö. 142/759) farklı konuları ihtiva eden telif ve tercüme eserleri, özellikle de Abbâsî Halifesi Ebû Ca'fer el-Mansûr'a (136-158 / 754-775) hitaben yazdığı Risâletü’s-sahâbe adlı mektubu, Ebû İshak es-Sâbînnin (ö. 384/984) Abbâsî halifeleri Mutî‘-Lillâh (334-364 / 946-974), Tâi'-Lillâh ile (363-381 / 974-991) Büveyhî emîrleri Muizzüddevle (334-356 / 945-967), İzzüddevle Bahtiyâr (356-367 / 967-978), Adudüddevle (367-372 / 978-983) ve Samsâmüddevle (372-376/983-987, 379-388/989-998) adına kaleme alınmış bazı resmî yazışmaları ihtiva eden mektupları ve KāimBiemrillâh (422-467 / 1031-1075) döneminden itibaren elli yılı aşkın bir süre Dîvânü’l-inşầda önce kâtiplik, daha sonra söz konusu divanın reisliğini yapan Emînüddevle İbnül-Mûsalâyânın muhtelif konularla ilgili yazmış olduğu mektupları bu tarz kaynaklara örnek olarak zikredilebilir.

İbnü'l-Mûsalâyâ tarafından yazılan bu mektupların sadece ikinci bölümü ve muhtemelen çok az bir kısmı zamanımıza kadar ulaşmıştır. 8 Cemâziyelâhir 603 (10 Ocak 1207) tarihinde ismi bilinmeyen bir müstensih tarafından bir araya getirilen ve tek yazma nüshası Tunus Millî Kütüphanesi'nde bulunan bu mektuplar İsâm Mustafa Akle tarafından 1997 yılında Ürdün Üniversitesi'nde doktora tezi (el-Hilâfetü’l-Abbâsiyye fî dav'i resâili Emîniddevle, dirâse ve't-tahkỉk) olarak hazırlanmış ve 2003 yılında Resâilü Emîniddevle İbni'l-Mûsalâyâ adıyla kitap olarak yayımlanmıştır. Yazar dirâse ve tahkik olmak üzere iki bölüme ayırdı̆̆ 1 eserinin ilk kısmında İbnü’l-Mûsalâyầnın hayatını, yaşadığı dönemin siyasî ve idarî durumunu ve Abbâsî-Selçuklu ilişkilerini incelemiş, ikinci kısmında ise mektupların tahkikli neşrine yer vermiştir.

451-491 (1059-1097) yılları arasını ihtiva eden ve sayısı altmış altıyı bulan bu mektupların üç tanesi İbnü’l-Mûsalâyâ tarafından şahsî olarak Selçuklu vezirleri Amîdülmülk el-Kündürî ve Nizâmülmülk'e, ayrıca Mezyedîler'in (387-558 / 997-1163) ${ }^{1}$ Kûfe ile Bağdat arasında yer alan merkezi Hille’de

1 Irak’ın güneyinde hüküm sürmüş bir hanedan (geniş bilgi için bk. Özaydın, "Mezyedîler", s. 550-51). 
ikamet eden dönemin tanınmış hıristiyan doktorlarından Mu'temidüddevle Ebü'l-Ferec Yahyâ b. Saîd b. Tilmîz'e² (ö. 512/1118) hitaben yazılmıştır. Bunların dişında kalan yedi tanesi Muktedî-Biemrillâh, bir tanesi MüstazhirBillâh (487-512 / 1094-1118), kırk yedi tanesi de Kāim-Biemrillâh adına yazılmıştır. Geriye kalan sekiz tanesinin ise kimin adına ve kime yazıldığı bilinmemektedir. ${ }^{3}$ Bu mektupların büyük bir kısmı Abbâsî halifeleri adına Tuğrul Bey (431-455 / 1040-1063), Alparslan (455-465 / 1063-1072), Melikşah (465-485 / 1072-1092) gibi Selçuklu sultanlarıyla Amîdülmülk el-Kündürî ve Nizâmülmülk gibi Selçuklu vezirlerine yazıldığ i için Abbâsî-Selçuklu ilişkilerine dair kıymetli bilgiler içermektedir. Diğer taraftan bu mektupların içinde İbn Dârest ve Fahrüddevle Muhammed b. Cehîr'in vezirliğe, bir kişinin de kādılkudatlığa tayin edilmesiyle ilgili halife tarafından çıkarılan tevkíc metinlerinin bulunması ve bazı divanlar hakkında kısa da olsa birtakım bilgiler verilmesi söz konunu mektupların Abbâsî idarî tarihi açısından da önemli birer kaynak olduğunu göstermektedir.

Günümüze tek yazma nüsha halinde ulaşan İbnü'l-Mûsalâyẩnın bu mektuplarının sadece birkaç tanesinin muhtevasıyla ilgili tarih kaynaklarında bilgiler verilmiştir. Mesela İbnüll-Cevzî, Kāim-Biemrillâh’̉n kendisinden sonra tahta çıkacak olan torunu Muktedî-Biemrillâh (467-487 / 1075-1094) için İbnü’l-Mûsalâyâya yazdırdığı tevkīi metnini eserinde zikretmiştir. ${ }^{4}$ Sadreddin el-Hüseynî, Büyük Selçuklu Sultanı Alparslan’n (456-465 / 1064-1072) Doğu Roma İmparatoru Romanos Diogenes’e (1067-1071) karşı gerçekleştirdiği ve Malazgirt Muharebesi (27 Zilkade 463 / 26 Ağustos 1071) olarak bilinen savaşta Selçuklu kuvvetlerinin galip gelmesi için Kāim-Biemrillâh tarafından İbnüll-Mûsalâyâya yazdırılan ve cuma namazında okunması için hatiplere gönderilen dua metinini eserine almıştır. ${ }^{5}$ Yine Memlük tarihçilerinden Kalkaşendî, İbnü'l-Mûsalâyâ tarafından kaleme alınmış olan Kāim-Biemrillâh’n veziri Fahrüddevle’ye gönderdiği mektubu, ${ }^{6}$ Mârî Abdi Yesû́un hıristiyanların patrikliğine atandığına dair tevkī metnini ${ }^{7}$ ve

2 İmâdüddin el-İsfahânî ve Yâkūt el-Hamevî, Mưtemidüddevle'nin lakabını Mưtemidülmülk olarak zikretmiş, ayrıca Yâkūt el-Hamevî onun 590 (1193) yılında oldukça geç bir tarihte vefat ettiğini aktarmıştır (bk. İmâdüddin el-İsfahânî, Harîdetü'l-kasr, III/2, s. 119; Yâkūt el-Hamevî, Mu'cemü'l-üdebâ', VI, 2819).

3 Mektupların kaç yılında kimin adına kime yazıldığı ve muhtevasıyla ilgili tablo için bk. Akle, "Dirâse", s. 51-54.

4 İbnü'l-Cevzî, el-Muntazam, XVI, 162-63.

5 Hüseynî, Ahbârü'd-devleti's-Selcûkıyye, s. 33-34; bu dua metni için ayrıca bk. İbnü'lAdîm, Bugyetü't-taleb, IV, 1978-79.

6 Kalkaşendî, Subhu'l-a aşâ, VI, 415-19.

7 Kalkaşendî, Subhu'l-a'şâ, X, 294-99. 
Kāim-Biemrillâh’’n Selçuklu Emîri Atsız b. Uvak’a (ö. 471/1079) gönderdiği mektubu ${ }^{8}$ eserinde zikretmiştir.

İbnü’l-Mûsalâyẩnın mektupları, yukarıda da ifade edildiği üzere, özellikle Abbâsî-Selçuklu ilişkilerine dair çok önemli bilgiler ihtiva etmesine rağmen, Türkiye'deki akademik çalışmalarda gereken ilgiyi görmemiştir. Bundan dolayı biz de birinci elden kaynak olması hasebiyle söz konusu mektupları hem araştırmacıların dikkatine sunmak hem de Abbâsî idarî tarihi açısından incelemek istedik. İki ana başlıktan oluşan çalışmada önce İbnü'l-Mûsalâyầnın hayatı ele alınmış, ardından söz konusu mektuplardan hareketle vezirlik, kādılkudatlık ve bazı divanların V. (XI.) asırdaki durumuyla ilgili bilgi verilmiştir.

Mektuplarla ilgili önemli bir hususun altının çizilmesi gerekir ki, inşâ kâtipleri kendi hünerlerini ve hilafet makamının yüceliğini göstermek amacıyla yazdıkları metinlerde oldukça ağdalı bir dil kullandıkları için bu metinlerin lafzî/literal tercümesi mümkün değildir. Bundan dolayı burada Akle’nin kitabının dirâse kısmında verdiği bilgilerden ve mektupları neşrederken dipnotlarda yaptığı açıklamalardan da istifadeyle mektupların ancak muhtevası yansitılmaya çalışılmıştır.

\section{A. İbnü'l-Mûsalâyâ’nın Hayatı}

Tam adı Ebû Sa'd Alâ b. Hasan b. Vehb b. Mûsalâyâ olup kaynaklarda daha çok hıristiyan asıllı büyük dedesine nispetle İbnü’l-Mûsalâyâ olarak anılan Ebû Sa'd Alâ b. Hasan 6 Şevval 412 (13 Ocak 1022) tarihinde Bağdat'in Kerh semtinde dünyaya geldi. ${ }^{9}$ Ancak ailesinin kökenlerinin Musul asıllı olduğu söylenmektedir. ${ }^{10}$

Kaynaklarda İbnüll-Mûsalâyầnın (ابن الموصلايا) isminin okunuşuyla ilgili doğrudan bir bilgi bulunmamaktadır. Ancak farklı eserlerin nâşirleri bu ismi İbnü'l-Mûsalâyâ şeklinde okumayı tercih etmiştir. ${ }^{11}$ Bununla birlikte mektupları neşreden Akle, kitabın birkaç yerinde vav harfini cezimli bir şekilde harekeleyerek söz konusu ismi İbnül-Mûvsalâyâ olarak okumuş, ${ }^{12}$ eserin kapağında ise diğer nâş̧irlerin okuyuşunu tercih etmiştir. Esasen Aklennin metin içindeki bu tercihinin ilk bakışta İbnü’l-Mûsalâyânın isminin yanlış

8 Kalkaşendî, Subhu'l-a $a$ şâ, VI, 453-56.

9 İbnü'd-Dimyâtî, el-Müstefâd, s. 159.

10 Yâkūt el-Hamevî, Mu'cemü'l-üdebâ', III, 1023.

11 İbn Hallikân, Vefeyâtü’l-a'yân, III, 480; Zehebî, Siyeru a'lâmin-nübelâ', XIX, 198; Kalkaşendî, Subhu'l-a ş̧â, VI, 415, 453, X, 294.

12 Bazı örnekler için bk. Akle, "Dirâse", s. 35, 36, 37. 
okunmasına sebebiyet verebileceği düşünülebilir. Ancak kitabın kapağındaki yazı dikkate alınırsa, aslında onun bunu vav harfinin harekeli olmadığını göstermek için yaptığı ifade edilebilir. Dolayısıyla ismin doğru okunuşunun İbnü'l-Mûsalâyâ şeklinde olması gerekmektedir. Konuyla ilgili zikredilmesi gereken bir diğer husus Mûsalâyâ isminin nereden geldiğidir ki, kaynaklarda bununla ilgili herhangi bir açıklama bulunmamaktadır. Ancak, yukarıda ifade edildiği üzere, İbnü’l-Mûsalâyânın ailesinin Musul kökenli olmasından dolayı buraya nisbetle, okuyuş açısından kısmen değişikliğe uğrayarak Mûsalâyâ şeklinde bir isim verilmiş olabilir.

Irak Büveyhîleri’nin (334-447 / 945-1055) Abbâsîler üzerindeki etkisinin giderek zayıfladığı bir dönemde yaşayan İbnü’l-Mûsalâyâ meslekî açıdan kâtip bir ailenin içinde yetişmiştir. Ailenin muhtemelen Abbâsî idarî tarihindeki ilk temsilcilerinden biri, babası Hasan b. Vehb'dir (ö. 427/1035-6). Kāim-Biemrillâh (422-467 / 1030-1074) döneminde Dîvânü'l-inşầda görevli olan İbn Vehb'in kâtiplik mesleğindeki maharetinden övgüyle söz eden Yâkūt el-Hamevî onun yazı üslubunun, hattatllğ̆ ile meşhur Abbâsî Veziri İbn Mukle’nin (ö. 328/940) hattını andırdığını söylemektedir. ${ }^{13}$

İbn Vehb dişında dönemin kâtiplerinden olan bir diğer kişi İbnüllMûsalâyẩnın kız kardeşinin oğlu Tâcürrüesâ Ebû Nasr Hibetullah b. Hasan b. Ali'dir (ö. 498/1105). Kāim-Biemrillâh, Muktedî-Biemrillâh ve MüstazhirBillâh dönemlerinde Dîvânü'l-inşẩda dayısının yanında kâtiplik yapan Ebû Nasr Hibetullah, yaşlılığının da etkisiyle ömrünün sonlarına doğru imla becerisini yitiren İbnü'l-Mûsalâyânın mektuplarını yazmıştır. ${ }^{14}$ Ebû Nasr Hibetullah’ın kâtip olarak yetişmesinde önemli bir etkisi olan İbnü'l-Mûsalâyâ, zaman zaman Bağdat dışındaki kişilere kendi yazdığı mektupları ulaştırması için Ebû Nasr’’ görevlendirmiştir. Nitekim dönemin önde gelen hıristiyan doktorlarından Mu'temidüddevle Ebü’l-Ferec Yahyâ b. Saîd b. Tilmîz, Bağdat'ta kendisine ait evin alıkonulması üzerine İbnü’l-Mûsalâyầdan kendi adına Selçuklu idaresi nezdinde girişimde bulunmasını talep etmiştir. Anlaşıldığı kadarıyla İbnü’l-Mûsalâyâ da bu konuyu araştıracağını ve gereken ne ise yapılması için Mu'temidüddevle’ye yardımcı olacağını bildirmiştir. ${ }^{15}$

13 Bk. Mu'cemü’l-üdebâ', III, 1023. Yâkūt el-Hamevî, İbn Vehb ile ilgili bilgi verdiği kısımda onun hem Kāim (Biemrillâh) hem de Mưtemid döneminde Dîvânüll-inşầda kâtiplik yaptığını söylemektedir. Ancak burada ismi geçen ikinci halifenin Mưtemid-Alellâh (256-279 / 870-892) olması muhtemeldir. Bu durumda söz konusu bilginin yanlış aktarıldığı belirtilmelidir. Zira Mútemid, İbn Vehb’in vefatından yaklaşık bir asırdan biraz daha uzun bir süre önce halifelik yapmıştır.

14 İmâdüddin el-İsfahânî, Harîdetü'l-kasr, I, 123, 132; İbn Hallikân, Vefeyâtü̉l-a'yân, III, 480.

15 İbnü'l-Mûsalâyâ, Resâil, s. 304-307; Akle, “Dirâse”, s. 37. 
Dîvânü'l-inşẩdaki görevi sırasında İbnü’l-Mûsalâyânın gözetiminde iyi bir kâtip olarak yetişen Ebû Nasr dayısının vefatından sonra bu divanın başına tayin edilmiştir. ${ }^{16}$

Yukarıda adları sayılan kişilerin dışında kaynaklarda İbnü’l-Mûsalâyâ ailesine mensup olduğu anlaşlan, ancak Ebû Saîd Alâ ile akraba olup olmadıklarına dair haklarında herhangi bir bilgi verilmeyen başka şahıslardan da bahsedilmektedir. Mesela Bağdat'ta Dîvânü'z-zimâm kâtiplerinden Ebü’l-Hüseyin b. Mûsalâyâa ${ }^{17}$ (ö. 487/1094) ve Kāim-Biemrillâh döneminin önde gelen hıristiyanlarından olduğu anlaşılan Ebü'l-Hayr Saîd b. Mansûr b. Mûsalâyâ bu kişilerdendir. ${ }^{18}$

Kaynaklarda İbnü'l-Mûsalâyẩnın evlenip evlenmediği, şayet evlendiyse de hanımı ve çocukları hakkında herhangi bir malumat bulunmamaktadır. Diğer taraftan geride bir vâris bırakmadığı anlaşılan İbnü'l-Mûsalâyầnın vefatı sırasında malının tamamını hayır işlerinde kullanılmak üzere vakfettiği zikredilmektedir. $^{19}$

İbnü'l-Mûsalâyâ henüz yirmili yaşlarda iken Kāim-Biemrillâh döneminde Dîvânü'l-inşẩda kâtip olarak görev yapmaya başlamış $(432 / 1040)^{20}$ ve bir süre sonra söz konusu divanın reisliğine tayin edilmiştir. Kaynaklarda İbnü'l-Mûsalâyânın bu göreve tam olarak ne zaman atandığına dair doğrudan bir bilgi bulunmamaktadır. Günümüz araştırmacılarından İsâm Akle, İbnü'l-Cevzî̀yi ${ }^{21}$ kaynak göstererek, muhtemelen (halifenin kâtibi) İbnü’lMüslime’nin vezirliğe tayin edilmesinin ardından boşta kalan Dîvânü’linşâ reisliğine söz konusu divanda yaklaşık on yıldır görev yapan İbnü’lMûsalâyânın atandığını söylemektedir (443/1051). ${ }^{22}$ Benzer bir bilgiye yer veren Yâkūt el-Hamevî ise İbnü'l-Mûsalâyầnın 443 (1051) yllından sonra Dîvânü'l-inşẩnın başına tayin edildiğini, o sırada ise bu görevi Amîdürrüesâ Ebû Tâlib b. Eyyûb’un yerine getirdiğini nakletmektedir. ${ }^{23}$ Öncelikle İbnü’lCevzînnin eserinin ilgili kısmında böyle bir bilginin yer almadığı belirtilmelidir. Yâkūt el-Hamevînin aktardığı kayıtta ise muhtemel bir bilgi karışıklığı

16 İmâdüddin el-İsfahânî, Harîdetü̉l-kasr, I, 132.

17 İbnül-Esîr, el-Kâmil, X, 240.

18 Mârî b. Süleyman, Ahbâru Fetârike, s. 122, 124.

19 Zehebî, Siyeru a'lâmin-nübelâ', XIX, 198-199.

20 İmâdüddin el-İsfahânî, Harîdetül-kasr, I, 123; Yâkūt el-Hamevî, Mu'cemü'l-üdebầ, IV, 1635; İbn Hallikân, Vefeyât, III, 480.

21 İbnü'l-Cevzî, el-Muntazam, XV, 333.

22 Akle, "Dirâse", s. 39. İbnü’l-Müslime’nin vezirliğiyle ilgili geniş bilgi için bk. Hançabay, Abbâsîler Döneminde Vezirlik, s. 268-83.

23 Yâkūt el-Hamevî, Mu'cemü'l-üdebâ', IV, 1635. 
göze çarpmaktadır. Şöyle ki, Dîvânü'l-inşânın başında olduğu söylenen Ebû Tâlib b. Eyyûb, İbnü’l-Müslime'den önce halifenin şahsî kâtipliğini yapmış ve 437 (1045-6) yılında bu görevinden azledilmiştir. ${ }^{24}$ Bu tarihten sonra ise Ebû Tâlib b. Eyyûb’un herhangi bir resmî görev alıp almadığına dair kaynaklarda bir bilgi bulunmamaktadır. Netice itibariyle halifenin şahsî kâtipliğini yapan İbnü'l-Müslime’nin 8 Cemâziyelevvel 437 (21 Kasım 1045) tarihinde vezirliğe tayin edildiği göz önünde bulundurulursa, İbnüll-Mûsalâyẩnın 443 (1051) yılından daha önceki bir tarihte Dîvânü'l-inşâ reisliğine atandığı söylenebilir. Nitekim Bündârî de onun 430 (1038-9) yılından sonra bu göreve başladığını söylemektedir. ${ }^{25}$

İbnü’l-Mûsalâyâ, İbnü’l-Müslime’nin vezirliği döneminde, Dîvânü'linşẩnın reisliğini kısa süreliğine bırakmak durumunda kalmıştır. Şöyle ki, Ramazan 450 (Ekim-Kasım 1058) tarihinde dindar olduğu söylenen bazı kimseler Vezir İbnü’l-Müslime’ye gelerek devletin resmî kurumlarında görev yapan gayrimüslimlerin giyâr ${ }^{26}$ giymeleri ve görevlerinden uzaklaşt1rılmaları için vezire baskı yaptılar. Bunun üzerine başta Kāim-Biemrillâhı̉n hanımı Hatice Arslan Hatun'un yahudi asıllı kâtibi Ebû Ali İbn Fadlân ve İbnü'l-Mûsalâyâ olmak üzere divanlarda görevli bulunan gayrimüslimlerin görevlerine son verildi. Ancak durumdan haberdar olan Kāim-Biemrillâhỉn, söz konusu karara tepki göstermesinin ardından gayrimüslim kâtipler tekrar görevlerinin başına döndüler. ${ }^{27}$

Bu olaydan kısa bir süre sonra Tuğrul Bey'in (431-455 / 1040-1063), kardeşi İbrâhim Yinal tarafından başlatılan isyanı bastırmak için başşehirden ayrılmasını fırsat bilen Büveyhîler'in Bağdat şahnesi (askerî vali) Arslan elBesâsîrînin Bağdat'ı ele geçirmesi (8 Zilkade 450 / 27 Aralık 1058) üzerine Kāim-Biemrillâh, Musul Emîri Kureyş b. Bedrânı̉ı himayesine girerek Bağdat'a yaklaşı 45 fersah (280 km.) uzaklıkta bulunan Âne'deki Hadîse

24 İbnü'l-Esîr, el-Kâmil, IX, 530.

25 Bündârî, Zübdetün-Nusra, s. 81 .

26 Kaynaklarda gayrimüslimlerin giymek zorunda oldukları bir kıyafet türünü ifade etmek üzere kullanılan bir terimdir. Gıyâr başlangıçta giyilen elbisenin koluna veya omuz kısmına dikilen farklı renkteki bir kumaş parçası veya kurdele anlamına gelirken, zamanla kapsamı genişleyerek gayrimüslim zümrelerin giydikleri zünnar, şapka, şal, sarık gibi kıyafetleri ve hatta bazı âdetleri de ihtiva eder hale gelmiştir (gıyârla ilgili geniş bilgi için bk. Kılavuz, "Gıyâr”, s. 59; Abbâsîler döneminde özellikle hıristiyanlarla ilgili gıyâr uygulamaları için bk. Öztürk, İslâm Toplumunda Hiristiyanlar, s. 236).

27 İbnü'l-Cevzî, el-Muntazam, XVI, 3o. Akle, İbnü'l-Cevzî̀deki rivayete dayanarak gayrimüslim kâtiplerle ilgili verilen bu kararın değişmesinde Selçuklu idaresinin, özellikle de Kāim-Biemrillâhın hanımı Hatice Arslan Hatun'un etkili olduğunu dile getirmektedir. Ancak ilgili kaynakta buna dair bir bilgi yer almamaktadır ("Dirâse", s. 39). 
Kalesi'ne gitti. ${ }^{28}$ Arslan el-Besâsîrî ve kendisine destek olan kişiler başta Dârülhilâfe olmak üzere birçok yeri işgal ederek ele geçirdikleri değerli eşyaları yağmaladılar. Anlaşıldığı kadarıyla bu sırada diğer birçok kişi gibi başşehirden ayrılmak durumunda kalan İbnü'l-Mûsalâyầnın malları da Arslan elBesâsîrî tarafından müsadere edildi. ${ }^{29}$ Nitekim İbnüll-Mûsalâyâ bu olaydan birkaç yıl sonra (452/1060) Tuğrul Bey’in veziri Amîdülmülk el-Kündürî tarafından kendisine verilen ikta arazilerine Amîdülırâk Ebû Nasr tarafından el konulması üzerine sultanın vezirine hitaben bir mektup yazmıştır. Mektupta Arslan el-Besâsîrî tehlikesine işaret eden İbnü’l-Mûsalâyâ bütün mal varlı̆̆ının elinden gittiğini ve geride hiçbir şeyinin kalmadığını söylemiş, ancak bu ikta arazilerinin kendisine tevdi edilmesi durumunda borçlarının bir kısmını buradan elde edeceği gelirlerle ödeyeceğini belirtmiştir. ${ }^{30}$

Arslan el-Besâsîrî tehlikesinin bertaraf edilmesinden sonra Abbâsî tarihinde Selçuklu nüfuzu dönemi başlamıştır (451/1060). Bu süreçte bir taraftan Abbâsî halifeleriyle akrabalık bağı kurarak iki taraf arasındaki ilişkileri kuvvetlendiren Selçuklu sultanları, diğer taraftan birtakım müdahalelerle Abbâsîler üzerindeki siyasî, idarî ve ekonomik nüfuzlarını giderek arttırmışlardır. Selçuklu nüfuzunun başlangıç safhasında Dîvânü’l-inşânın reisliğini yapan İbnü’l-Mûsalâyâ gerek Abbâsî halifeleri gerekse Selçuklu sultanlarıyla yakın ilişkiler kurmuştur. Nitekim Yâkūt el-Hamevî, İbnü’l-Mûsalâyânın bu yönüne işaret ederek Abbâsî halifelerinin ve Selçuklu sultanlarının "İbnü’lMûsalâyâya güvendikleri kadar başka hiçbir kimseye güvenmediklerini” söylemektedir. ${ }^{31}$ Yine Nizâmülmülk’ü öven bir kaside yazarak önde gelen Şâfiî âlimlerinden İbn Fûrek'in (ö. 406/1015) torunu Ebû Bekir Ahmed b. Muhammed b. Hasan el-Fûrekî̀yi ${ }^{32}$ (ö. 478/1085) Selçuklu vezirine gönderen İbnü’l-Mûsalâyâ böylece Selçuklu devlet adamlarıla ilişkisini güçlendirmiştir. ${ }^{33}$ Diğer taraftan resmî işlerdeki isabetli kararlarıyla Abbâsî veziri Amîdüddevle Muhammed b. Cehîr'in güvenini kazanan İbnü'l-Mûsalâyâ ve yeğeni Ebû Nasr Hibetullah, vezir tarafından "devletin sağı ve solu" şeklinde övülmüss, hatta Amîdüddevle, İbnü’l-Mûsalâyâ ve yeğeninin görüşünü almadan herhangi bir konuda nihaî karar vermemiştir. ${ }^{34}$

28 Arslan el-Besâsîrînin bu süreçteki faaliyetleri ve Kāim-Biemrillâh'ın Bağdat'tan ayrılmasıyla sonuçlanan olaylar hakkında geniş bilgi için bk. İbnü'l-Esîr, el-Kâmil, X, 641644; Sıbt İbnü'l-Cevzî, Mirâtü̇z-zamân (Sevim), s. 35-41.

29 Akle, "Dirâse", s. 39-40.

30 İbnül-Mûsalâyâ, Resâil, s. 266-67.

31 Yâkūt el-Hamevî, Mu'cemü'l-üdebâ', IV, 1635.

32 Ebû Bekir el-Fûrekî hakkında bk. Sübkî, Tabakāt, IV, 79.

33 İmâdüddîn el-İsfahânî, Harîdetü'l-kasr, I, 128-29; ayrıca bk. I, 128, dn. 8.

34 İmâdüddin el-İsfahânî, Harîdetü'l-kasr, I, 124; Sıbt İbnü'l-Cevzî, Mirâtü̈z-zamân, VIII/1, s. 12. 
İbnü'l-Mûsalâyâ kırk yıldan daha uzun bir süre hırıstiyan olarak Dîvânü’l-inşẩnın reisliğini yaptıktan sonra Muktedî-Biemrillâh’n halifeliği döneminde İslamiyet'i kabul etmiştir. Yâkūt el-Hamevînin verdiği bilgiye göre 14 Safer 484 (7 Nisan 1091) tarihinde Muktedî-Biemrillâh müslüman olmayan kişilere giyâr giyme zorunluğu getirmiş, ${ }^{35}$ ancak bu emri yerine getirmek istemeyen bazı gayrimüslim kâtipler divanlardaki görevlerini bırakarak kaçmışlar, bazıları ise müslüman olmaya karar vermişlerdir. İbnüll-Mûsalâyâ ve yeğeni Ebû Nasr da halifenin bu kararından iki gün sonra (16 Safer) İslamiyet'i kabul etmiştir. ${ }^{36}$

Arap edebiyatı tarihçilerinden Şevkī Dayf, İbnü'l-Mûsalâyânın müslüman olduğu tarihle ilgili olarak kaynaklarda zikredilen bilgileri aktardıktan sonra İmâdüddin el-İsfahânîye dayanarak onun Kāim-Biemrillâh döneminde müslüman olduğunu öne sürmüş, bu iddiasına gerekçe olarak da İsfahânînin uzun yıllar Bağdat’ta kaldığını söylemiştir. ${ }^{37}$ Ancak günümüz araştırmacılarından İsâm Akle’nin de belirttiği üzere, ${ }^{38}$ İmâdüddin elİsfahânînin eserinde İbnü'l-Mûsalâyânın müslüman olduğuna dair iki yerde verilen bilgiler onun, Şevkī Dayf'ın iddia ettiği gibi Kāim-Biemrillâh döneminde değil, daha sonraki bir tarihte müslüman olduğunu göstermektedir. Nitekim bu kayıtların ilkinde İbnü'l-Mûsalâyầnın Muktedî-Biemrillâh’n halifeliği ile Ebû Şücâc Muhammed b. Hüseyin er-Rûzrâverînin vezirliği döneminde müslüman olduğu aktarılmaktadır. ${ }^{39}$ İkinci kayıtta ise Dîvânü'zzimâm reislerinden Tâcürrüesâ Ebû Gālib el-İsbâgỉnin (ö. 485/1091) Safer 484 (Nisan 1091) tarihinde yani İbnü’l-Mûsalâyầnın müslüman olmasından bir gün önce İslamiyet’i kabul ettiği zikredilmektedir. ${ }^{40}$

İbnü'l-Mûsalâyẩnın müslüman olmasından birkaç gün sonra dönemin veziri Ebû Şücâ‘ er-Rûzrâverî görevinden azledildi (19 Safer 484 / 12 Nisan 1091). Vezirin görevden alınmasından sonra yerine herhangi bir atama yapmayan Halife Muktedî-Biemrillâh, İbnü’l-Mûsalâyâyya Emînüddevle lakabı

35 Geniş bilgi için bk. Bündârî, Zübdetün-Nusra, s. 81; Öztürk, İslâm Toplumunda Hıristiyanlar, s. 251; Akle, "Dirâse", s. 43.

36 Mu'cemül-üdebâ', IV, 1633. Gayrimüslimlerle ilgili bu kararın alınmasında dönemin veziri Ebû Şücâ‘ Muhammed b. Hüseyin er-Rûzrâverînin etkili olduğu söylenmektedir. Şöyle ki, zimmîlerin müslümanlara üstünlük kurmaya ve müslümanların arasına karışmaya başladığını gören Rûzrâverî, onların müslümanlardan ayrılmasını sağlayacak önlemlerin alınması gerektiğini halifeye bildirdi. Bunun için de gayrimüslimlerin giyâr giymeleri ve cizye ödemeleri konusunda taviz verilmemesini istedi. Ancak onun bu tavrı toplumun her kesiminde bir huzursuzluğa sebep oldu.

37 Dayf, Târîhu'l-edebi'l-Arabî̀, s. 447-48.

38 Akle, "Dirâse", s. 43-44.

39 İmâdüddin el-İsfahânî, Harîdetü̉l-kasr, I, 123.

40 İmâdüddin el-İsfahânî, Harîdetül-kasr, I, 135. 
vererek kendisini vezirliğge vekâlet etmek üzere (nâibülvezir) görevlendirdi. ${ }^{41}$ Ayrıca İbnü'l-Mûsalâyâya önü açık, kolları geniş siyah bir elbise şeklinde olan dürrâa ve sarıktan müteşekkil bir hil'at giydirdi ve kendisini eyeri altından mamul bir ata bindirdi. Aynı şekilde yeğeni Ebû Nasr'a sarık ve cübbe takdim ettikten sonra onu da ata bindirdi. ${ }^{42}$

20 Ramazan 484 (5 Kasım 1091) tarihinde Bağdat’a gelen Selçuklu Sultanı Melikşah ve veziri Nizâmülmülk için düzenlenen karşılama merasimine dönemin kādılkudatı Ebû Bekir eş-Şâmî ve diğer devlet erkânıyla birlikte İbnü'l-Mûsalâyâ da nâibülvezir olarak katılmıştır. ${ }^{43}$ Amîdüddevle Muhammed b. Cehîr'in 27 Zilkade 484 (10 Ocak 1092) tarihinde ikinci defa vezirliğe atanmasıyla yaklaşık on ay sonra Dîvânü'l-inşầdaki görevine dönmüştür. ${ }^{44}$ Amîdüddevle’nin vezirliği döneminde ona en yakın kişilerden biri İbnü'l-Mûsalâyâ olmuştur. Nitekim Muktedî-Biemrillâh’ın vefatından sonra tahta çıkan Müstazhir-Billâh, yeni vezire, babasının vefat haberinin duyulmadan Selçuklu Sultanı Berkyaruk (485-489/1092-1104) ve beraberindeki emîrlerden ve ayrıca diğer devlet erkânından biat alınmasını emretmiş ve bu konuda İbnü'l-Mûsalâyâ ve yeğeni Ebû Nasr Hibetullah'in kendisine yardımcı olmasını istemiştir. İbnü’l-Mûsalâyâ da devlet ricali ve özellikle Selçuklu idaresi nezdinden herhangi bir sorun çıkmadan yeni halifenin tahta çıması için büyük bir gayret sarfetmiştir. ${ }^{45}$

Dokuz yıla yakın bir süre vezirlik yapan Amîdüddevle’nin Ramazan 493 (Temmuz-Ağustos 1100) tarihinde gözaltına alınarak görevinden azledilmesinin ardından Müstazhir-Billâh onun yerine hemen bir atama yapmamıştır. Bu noktada kaynaklarda yer alan bilgilerden hareketle söz konusu makama kimin vekâlet ettiğini belirlemek pek mümkün görünmemektedir. Günümüz araştırmacılarından Azzâm, İbnüll-Cevzî, İbnü'l-Esîr ve Zehebî gibi müelliflere dayanarak bu sırada vezirlik makamına Dîvânüll-inşâ reisi İbnüll-Mûsalâyầnın vekâlet ettiğini söylemektedir. ${ }^{46}$ Ancak ilgili kaynaklarda böyle bir bilgi yer almadığ 1 gibi ${ }^{47}$ İbnü’l-Esîr tarafından aktarılan kayıt İbnü'l-Mûsalâyẩnın bu görevi, aşağıda da zikredileceği üzere, Ebü’l-Mahâsin ed-Dihistânînnin vezirliğinden sonra yaptığını göstermektedir. ${ }^{48}$

\footnotetext{
41 İbnüll-Cevzî, el-Muntazam, XVI, 293; İbn Hallikân, Vefeyât, III, 48o.

42 Yâkūt el-Hamevî, Mu'cemü'l-üdebâ', IV, 1635.

43 İbnü'l-Cevzî, el-Muntazam, XVI, 293-94; Bündârî, Zübdetün-Nusra, s. 82-83.

44 Bündârî, Zübdetünn-Nusra, s. 81 .

45 İbnü'l-Cevzî, el-Muntazam, XVII, 12.

46 Azzâm, el-Vizâretüll-Abbâsiyye, s. 112.

47 İbnü'l-Cevzî, el-Muntazam, XVII, 62; Zehebî, Târîhu'l-İslâm, s. 25.

48 İbnül-Esîr, el-Kâmil, X, 307.
} 
Dört ay gibi kısa bir süre Müstazhir-Billâh’n vezirliğini yapan Ebü’lMehâsin ed-Dihistânî̉nin görevinden ayrılarak Selçuklu Sultanı Berkyaruk'un vezirliğine atanmasıyla İbnü'l-Mûsalâyâ bir defa daha vekâleten vezir olarak görevlendirilmiştir. Bu noktada kaynaklarda İbnü'l-Mûsalâyầnın bu görevi üstlendiğine dair doğrudan bir ifade yer almamaktadır. Ancak daha sonra vezirliğe atanacak olan Ebü'l-Meâlî el-İsfahânînin göreve başlamasından önce Bağdat'a gelen (18 Zilkade 494/24 Eylül 1100) Sultan Berkyaruk'u karşılamak üzere İbnü'l-Mûsalâyẩnın Müstazhir-Billâh tarafından görevlendirildiğine dair İbnü'l-Esîr ve İbn Haldûn'un aktardığı bilgi ${ }^{49}$ İbnü'l-Mûsalâyầnın vekâleten bu görevi yürüttüğünü göstermektedir. Nitekim daha önce de zikredildiği üzere, Melikşah ile Nizâmülmülk’ün Bağdat'a yaptıkları ziyaret sırasında düzenlenen karşılama merasimine nâibülvezir olarak İbnü’l-Mûsalâyâ da katılmıştı.

Bir buçuk yıl kadar nâibülvezir olarak görev yapan İbnü'l-Mûsalâyâ, Müstazhir-Billâhỉn Ramazan 495 (Haziran 1102) tarihinde ${ }^{50}$ Ebüll-Meâlî el-İsfahânîyi vezirliğe tayin etmesiyle tekrar eski görevine döndü. Ancak Ebü’l-Meâlînin 15 Receb 496 (24 Nisan 1103) tarihinde azledilerek gözaltına alınmasıyla yaklaşık on ay süren vezirlik görevi de sona erdi $^{51}$ ve İbnü’lMûsalâyâ üçüncü defa Müstazhir-Billâh tarafından vezirliğe vekâlet etmek üzere görevlendirildi. ${ }^{52}$ Bir aydan biraz daha uzun bir süre görev yapan İbnü'l-Mûsalâyâ, Şaban 496'da (Mayıs-Haziran 1103) yeğeni53 Zaîmürrüesâ Ali b. Fahrüddevle’nin vezirliğe tayin edilmesiyle ${ }^{54}$ yeniden Dîvânülinşâ’daki görevine döndü.

Bundan sonraki süreçte Dîvânül-inşâ reisliğinin dışında herhangi bir görev almadığı anlaşılan İbnü’l-Mûsalâyâ, ömrünün sonlarına doğru görme yetisini kaybetmiş ve 19 veya 22 Cemâziyelevvel 497 (18 veya 21 Şubat 1104) tarihinde Bağdat’ta vefat etmiştir. ${ }^{55}$

\footnotetext{
49 İbnü'l-Esîr, el-Kâmil, X, 307; İbn Haldûn, Târîh, III, 600.

50 İmâdüddin el-İsfahânî, Harîdetü̉l-kasr, I, 93; İbnül-Esîr, el-Kâmil, X, 351; Nüveyrî, Nihâyetül-ereb, XXIII, 148.

51 İbnü'l-Esîr, el-Kâmil, X, 362; İbn Haldûn, Târîh, III, 605-606.

52 İbnü'l-Esîr, el-Kâmil, X, 362; Nüveyrî, Nihâyetü'l-ereb, XXIII, 148; İbn Haldûn, Târîh, III, 606.

53 İbnül-Esîr, el-Kâmil, X, 350.

54 İbnü'l-Esîr, el-Kâmil, X, 366; Nüveyrî, Nihâyetü'l-ereb, XXIII, 148.

55 İmâdüddin el-İsfahânî, Harîdetül-kasr, I, 132; Yâkūt el-Hamevî, Mu'cemü’l-üdebầ, IV, 1635; İbn Hallikân, Vefeyât, III, 480.
} 


\section{B. Mektuplardaki Abbâsî İdarî Tarihiyle İlgili Bilgiler}

\section{Vezirlik}

Abbâsîler'le birlikte resmî bir kurum olarak ortaya çıkan vezirlik müessesi, II. (VIII.) asrın sonlarına doğru tam teşekküllü bir yapı haline gelmiş, III. (IX.) asrın sonlarından itibaren ise hemen hemen son kudretli dönemini yaşamıştır. Râzî-Billâh’ın (322-329/934-940) İbn Râik'i resmen emîrü’l-ümerâ olarak tayin etmesiyle (324/936) eski önemini kaybeden vezirlik kurumu, Büveyhîler'in Bağdat'ı ele geçirmesiyle de işlevini neredeyse tamamen yitirmiştir. Bu dönemde Büveyhî emîrlerinin kâtipleri vezirlerin yerini alırken, Abbâsî halifelerinin vezirleri de kâtip sıfatıyla halifelerin özel işlerini takip etmekle görevlendirilmiştir. Nihayet Büveyhîler'in Bağdat'taki varlıklarının sona ermesinden kısa bir süre önce Reîsürrüesâ İbnü’l-Müslime’nin KāimBiemrillâh tarafından resmen vezir olarak görevlendirilmesiyle vezirlik kurumu da işlerlik kazanmaya başlamıştır (437/1045). ${ }^{56}$

İbnü'l-Müslime’nin vezirliğinden sonraki dönemi kapsayan İbnü’lMûsalâyầnın mektuplarından sekiz tanesi vezirlik kurumunu ilgilendirmektedir. Bunlardan iki tanesi İbnü'l-Müslime’den sonra vezirliğe tayin edilen İbn Dârest'in söz konusu makama atanması sırasında Abbâsî halifeliği ile Selçuklu idaresi arasında yaşanan hadiselerle ilgilidir. Şöyle ki, Arslan el-Besâsîrînin bertaraf edilmesinden sonra Âne'deki Hadîse Kalesỉnden Bağdat'a dönen (24-25 Zilkade 451 / 2-3 Ocak 1060) Kāim-Biemrillâh, veziri İbnü'l-Müslime’nin öldürüldüğünü öğrenince onun yerine hemen bir atama yapmayıp, kâtibi Ebû Turâb b. Eserî̀yi vekâleten bu göreve tayin etmiş, böylece vezirlik makamı bir yıldan biraz daha uzun bir süre boş kalmıştır. Fakat daha sonra Kāim-Biemrillâh, İbn Dârest'i vezirliğe tayin etmek isteyince, onun "kifayetsiz ve dirayetsiz" olduğunu düşünen Tuğrul Bey adına veziri Amîdülmülk el-Kündürî halifeye bir mektup göndererek bu duruma itiraz etmiştir. İlgili kaynakların verdiği bilgilerden bu itirazın aslında Amîdülmülk'ün halifenin vezirliğine tayin edilmek istemesinden kaynaklandığı anlaşılmaktadır (15 Rebîülevvel 453 / 9 Mayıs 1061). ${ }^{57}$

Selçuklu idaresinin itirazına binaen hem Tuğrul Bey’e hem de veziri Kündürîye ayrı ayrı mektup gönderen Kāim-Biemrillâh, verdiği karardan dönmeyerek İbn Dârest'i vezirliğe tayin etmiştir. Tuğrul Bey’e gönderilen mektupta mevcut şartlar itibariyle Bağdat’ta vezirlik görevini deruhte edecek

56 Vezirlik kurumunun bu süreçteki tarihsel gelişimiyle ilgili geniş bilgi için bk. Hançabay, Abbâsîler Döneminde Vezirlik, s. 77-285.

$57 \mathrm{Bu}$ süreçteki gelişmeler hakkında bk. Sıbt İbnü’l-Cevzî, Mir'âtü'z-zamân (Sevim), s. 248; Bündârî, Zübdeü̉n-Nusra, s. 21-22. 
bir kişinin bulunmadığı, bundan dolayı vezirlik makamının bir yıldan daha uzun bir süre boş kaldığı ifade edilmektedir. Daha sonra İbn Dârest'in "güvenilir", "akîdesi halis", "mezhebi doğru", "yolu/usulü övülmeye değer” ve "kudretli” olduğu ve bu özelliklerinden dolayı kendisinin Bağdat’a çağrıldığı zikredilmektedir. ${ }^{58}$

"İlâ Mansûr b. Muhammed" başlı̆̆ıyla Amîdülmülk el-Kündürîye hitaben yazılan mektupta onun devletin maslahatı için samimi bir şekilde gayret sarfettiği belirtilmektedir. Ayrıca Tuğrul Bey'in adına gönderilen mektupta bu işi üstlenmesi için kendisinin adının geçtiği, hatta Tuğrul Bey’i bu konuda kendisinin teşvik ettiği zikredilmektedir. Ancak halifenin emrinde çalışacak en uygun kişinin belirlenmesinde, hatta İbn Dârest' in bu konuda istekli olmas1 ve buraya gelmesi konusunda Kündürî ile istişare edildiğinde, Kündürînin, İbn Dârest'in sahip olduğu meziyetleri sıralayıp onu övdüğü, hatta Ahvaz’da onunla karşılaştığında kendisinde bıraktığı güzel izlenimlerden bahsettiği anlatılmaktadır. Ardından İbn Dârest' in Vâsıt'tan ayrılıp Bağdat'a doğru yola çıktığ herhangi bir özrün söz konusu olamayacağg söylenmektedir. ${ }^{59}$

Kāim-Biemrillâh’̉n Tuğrul Bey ve veziri Kündürîye gönderdiği mektuplardan sonra kronolojik açıdan İbnü’l-Mûsalâyânın yazdı̆̆ iki mektup İbn Dârest ve Fahrüddevle İbn Cehîr'in vezirlik makamına atandıklarına dair halife tarafından çıkarılan tevkīi metinleriyle ilgilidir. Vezirlik kurumunun ihdas edildiği ilk dönemlerden itibaren halifeler bu makama atadıkları kişiler için tevkī çıkarmış, vezirliğe namzet olan kişiler de böylece görevlerine başlamışlardır. Abbâsîler döneminde her vezirin tayini için bir tevkī‘ çıkarılmış olmasına rağmen, kaynaklarda çoğu zaman halifenin sadece tevkí çıkardığı söylenmiş, ${ }^{60}$ tevkīlerin muhtevasıyla ilgili ise birkaçı dışında ${ }^{61}$ hemen hemen hiçbir bilgi verilmemiştir. İbn Dârest ve Fahrüddevle İbn Cehîr'in vezirlik makamına atanmasıyla ilgili İbnü'l-Mûsalâyâ tarafından kaleme alınan tevkï metinleri bu açıdan önem arzetmektedir.

"Kitâbün enşeehû 'inde cülûsi İbn Dârest fi'l-vizâre" başlığıyla İbn Dârest'in vezirliğe tayin edildiğine dair yazılan tevkīde, önce halifeyi öven

58 İbnüll-Mûsalâyâ, Resâil, s. 382-84.

59 İbnü'l-Mûsalâyâ, Resâil, s. 385-87.

6o Bazı örnekler için bk. İbn Miskeveyh, Tecâribü’l-ümem, I, 219; İbnü’l-Cevzî, el-Muntazam, XV, 331; Bündârî, Zübdeün-Nusra, s. 79.

61 Sıbt İbnü’l-Cevzî, Fahrüddevle’nin 454 (1062) yılında vezirliğe tayin edildiğine dair halifenin çıkardığ sar bir şekilde aktarmıştır (bk. Mirâtü̈z-zamân [Sevim], s. 449-50). Bündârî ise sadece tevkī‘ çıkarıldığını zikretmiştir (bk. Zübdeün-Nusra, s. 23). 
açıklamalara yer verilmektedir. Ardından vezirlik makamına tayin edilecek kişinin "gayretli", "davranışlarının övgüye şayan" olması gibi birtakım hasletleri taşıması gerektiğinden bahsedilmekte, ardından (Bağdat’ta) bu özellikleri taşıyan bir kişi bulunmadığ için vezirlik makamının (bir süredir) boş olduğu ifade edilmektedir. Daha sonra İbn Dârest'in sahip olduğu ahlakî meziyetler sıralanarak kendisine Emînüddevle Mecdilvüzerâ lakaplarının verildiği ve emîrüll-mü’minînin kendisini vezirlik makamına tayin ettiği bildirilmektedir. Mektubun kalan kısmında ise yeni vezire bazı nasihatlerde bulunulmaktadır. ${ }^{62}$

"Kitâbün enşeehû 'inde cülûsi Fahriddevle İbn Nasr b. Cehîr fi'l-vizâre" başlığıyla Fahrüddevle’nin (6 Rebîülevvel 461 [3 Ocak 1069] tarihinde ikinci defa) vezirliğe tayin edilmesiyle ilgili yazılan tevkīi metni İbn Dârest'inkinden farklı olarak uzunca bir hamdele (Allah'a hamd) ve salvele (Hz. Peygamber'e salavat) kısmıyla başlamaktadır. Ardından Kāim-Biemrillâh’n (8 Zilkade 460 [8 Eylül 1068] tarihinde) kısa süreliğine Fahrüddevle’yi görevinden almasına işaret edilerek bunun Allah Teâlânın takdiri olduğu ve bu süre zarfında vezirlik makamının boş kaldığı ifade edilmektedir. Ayrıca Fahrüddevle’nin sahip olduğu özelliklerden bahsedilerek kendisinin vezirliğe tayin edildiği zikredilmektedir. Son kısımda ise önceki tevkíde olduğu gibi yeni vezire Allah'tan korkması ve adaletle hükmetmesi şeklinde nasihat cümlelerine yer verilmektedir. ${ }^{63}$

Kāim-Biemrillâh, Fahrüddevle’nin tekrar vezirliğe atanmasıyla ilgili Alparslan’a da "Nüshatü kitâbin ilâ Adudiddevle fî ma'na'd-dîvâni'l-azîze" başlığını taşıyan bir mektup göndermiştir. Söz konusu mektupta halifenin verdiği karar ayrıntılı olarak anlatılmakta, ayrıca Fahrüddevle’ye gönderilen mektuptan farklı olarak vezirin iki oğlu Amîdüddevle Muhammed ve Zaîmürrüesâ Ali’ye de resmî işlerle meşgul olmaları için izin verildiği belirtilmektedir. ${ }^{64}$ Yine aynı meseleyle ilgili olarak "Nüshatü mâ harace fî hakki Amîdiddevle b. Cehîr" adıyla yazılan tevkī'de Amîdüddevle’nin bazı hasletlerinden bahsedilerek onun devlet idaresindeki yeterliliğine vurgu

62 İbnü'l-Mûsalâyâ, Resâil, s. 222-23.

63 İbnü'l-Mûsalâyâ, Resâil, s. 226-29. Kalkaşendî, Fahrüddevle Muhammed b. Cehîr'in Kāim-Biemllâh tarafından 472 (1079-1080) yılında vezirliğe tayin edildiğine dair İbnü’l-Mûsalâyầnın bir tevkī‘ yazdığını söylemektedir (bk. Kalkaşendî, Subhu'l-a ş̧âa, X, 234-37). Ancak Kāim-Biemrillâh’in 467 (1075) yılında vefat ettiği, Fahrüddevle’nin de 16 Safer 471 (27 Ağustos 1078) tarihinde Muktedî-Biemrillâh’n vezirliğinden ayrıldıktan (İbnü'l-Cevzî, el-Muntazam, XVI, 198; Sıbt İbnü'l-Cevzî, Mirâtü̈z-zamân [Sevim], s. 196) sonra bir daha Abbâsîler'in hizmetinde bulunmadığı göz önünde bulundurulursa, Kalkaşendînin metnini verdiği tevkīin başka bir kişiyle ilgili olduğu söylenebilir.

64 İbnü’l-Mûsalâyâ, Resâil, s. 252, 254, 255, dn. 4. 
yapılmaktadır. ${ }^{65} \mathrm{Bu}$ sırada yaşanan gelişmelerle ilgili bazı bilgiler veren Bündârî, Fahrüddevle'nin vezirliğe atandıktan sonra iki oğluyla birlikte at üstünde Bağdat'ın batı yakasındaki bütün semtleri dolaştığını, Kerh bölgesine geldiklerinde halkın, üzerlerine altın ve gümüş saçarak kendilerine büyük bir teveccüh gösterdiğini belirtmektedir. ${ }^{66}$

Büveyhîler'in Bağdat'taki hâkimiyetlerinin sona ermesinin ardından zaman zaman Selçuklu devlet adamlarının Abbâsî halifesi tarafından yapılan atamalara müdahale etmesi, iki taraf arasındaki ilişkilerin gerilmesine sebep olmuştur. Nitekim yukarıda da zikredildiği üzere İbn Dârest' in vezirliğe atanma sürecinde Tuğrul Bey ve veziri Kündürînin bütün ısrarlarına rağmen Kāim-Biemrillâh verdiği karardan dönmemiştir (453/1061). Bu olaydan yaklaşık on yıl sonra (Rebîülevvel 464 / Kasım-Aralık 1071) bu sefer Alparslan, veziri Nizâmülmülk'ün de etkisiyle, benzer bir teşebbüste bulunarak Ebü’lAlâ Muhammed b. Hüseyin'i vezîrülvüzerâ unvanıyla Bağdat’a gönderdi. Ancak Fahrüddevle'yi vezirlikten azletmek istemeyen Kāim-Biemrillâh, Ebü'lAlầyı hiç kimsenin karşılamamasını emretti. Bunun üzerine dönemin Bağdat şahnesi Sâdüddevle Gevherâyîn, Selçuklu sultanının mektubunu halifeye ileterek Fahrüddevle'nin yerine vezirliğe Ebü'l-Alânın atanmasını istedi. ${ }^{67}$ Yaşanan gelişmeler üzerine Kāim-Biemrillâh, Alparslan’a bir mektup gönderdi. "Nüshatü'l-kitâbi'l-eşref ilâ Adudiddevle" başlığı ile İbnü'l-Mûsalâyâ tarafından yazılan mektupta Alparslan’n Ebü’l-Alâyı sözünde ve davranışlarında güvenilir bulduğu ve işinin ehli biri olarak gördügü söylenmektedir. Ancak Ebü'l-Alẩnın sanıldığı kadar güvenilir olmadığı, dinî ve mezhebî açıdan fâsık olmakla itham edildiği belirtilmekte, dahası bütün bu özellikleri hâiz birinin nasıl olur da vezirliğe namzet gösterilebileceği ifade edilmektedir. Ardından Fahrüddevle’nin sahip olduğu idarî ve ahlakî meziyetler sıralanarak, Selçuklu idaresinin kendisi hakkındaki ithamlarının doğru olmadığı açıklanmaktadır. Mektubun devamında Büveyhîler'le Selçuklular kıyaslanarak Büveyhî emîrlerinin Şiî olmalarına rağmen (yapılacak atamalarda) kendi başlarına buyruk hareket etmeyip Abbâsî halifesine başvurdukları söylenmektedir. Son kısımda ise devletin mansur olduğu, nizama istikrar kazandırdığı, bayrağının (hâkimiyet) yayıldığı, Haremeyn ve Bilâdüşşam'da hutbelerin artık halife adına okunduğu bildirilmektedir. ${ }^{68}$

Vezirlik kurumuyla ilgili İbnü'l-Mûsalâyânın kaleme aldığı sekizinci ve son mektup Muktedî-Biemrillâh tarafından Selçuklu Sultanı Melikşahı̉n

65 İbnü'l-Mûsalâyâ, Resâil, s. 230-31.

66 Bündârî, Zübdetün-Nusra, s. 34 .

67 Sıbt İbnü’l-Cevzî, Mirâtü̈z-zamân (Sevim), s. 155-56; Bündârî, Zübdetü’n-Nusra, s. 42-43. 68 İbnül-Mûsalâyâ, Resâil, s. 409-13. 
hanımı Terken Hatun’a gönderilmiştir. Amîdüddevle’nin ikinci vezirliğinden azledilmesinin ardından Benî Cehîr ailesi halifenin izni olmaksızın Dârülhilâfe'den ayrılarak önce Selçuklu idaresinin Bağdat'taki yönetim merkezi olan Dârülmemleke’ye, oradan da Selçuklu başşehri İsfahan’a gitmişlerdir (Rebîülevvel 476 / Temmuz-Ağustos 1083). Benî Cehîr ailesinin bu şekilde Bağdat'tan ayrılmasına öfkelenen ve Melikşah’a bir mektup gönderen Muktedî-Biemrillâh artık onların geri dönmesinin ve resmî bir görev almalarının mümkün olmadığını söyleyerek, Melikşah’tan onları himaye etmemesini istemiştir. ${ }^{69}$ Muktedî-Biemrillâh ayrıca Melikşah’ın hanımı Terken Hatun'a da bir mektup göndermiştir. "Nüshatü kitâbin ile'l-hâtûn" başlığını taşıyan ve baş tarafından Terken Hatun’a övgülerin yer aldığı mektupta Benî Cehîr ailesinin bütün fesat kapılarını açtığı, (davranışları itibariyle toy oldukları, yani) kendilerine yaşl1lıktan sonra gençliğin geri geldiği, (bu durumun etkisiyle) amaçlarındaki gizli ve açık bütün kötülükleri ortaya koydukları anlatılmakta, bundan dolayı halifelik divanından Terken Hatun'la görüşme/yardımlaşma kararı çıktığı anlatılmaktadır. Ardından hain olarak adlandırılan Benî Cehîr ailesinin Selçuklu himayesinden uzaklaştırılması için Terken Hatun'dan himmet etmesi istenmektedir. ${ }^{70}$ Söz konusu mektubun ilk defa bir hanıma gönderilmesi ve elçi olarak görevlendirilen kişinin isminin mektupta zikredilmesi -Cemâlüddevle Emînülhadrateyn Ebü’l-Fedâil Afîf el-Kāimî- diğer mektuplarda hemen hemen hiç karşılaşılmayan bir durum olarak dikkat çekmektedir.

\section{Kādılkudatlık}

İslam tarihinde kadı tayinlerinin Hulefâ-yi Râşidîn döneminden itibaren yapıldığı ve farklı bölgelerde görevlendirilen bu kadıların yetkileri ve sorumlulukları itibariyle aralarında herhangi bir farkın olmadığı bilinmektedir. Ancak Hârûnürreşîd'in (170-193/786-809) Ebû Yûsuf'u (ö. 182/798) kādılkudat olarak atamasıyla kadılık kurumu içinde hiyerarşik bir yapının ortaya çıktığı ve bu düzenlemenin sonraki İslam devletlerinin idarî yapısında da etkili olduğu görülmektedir. Kādılkudatlığın ihdas edilmesinden sonra bu göreve atanan kişilerin yetkilerinin tedricî bir şekilde arttığ 1 ve devletin hâkim olduğu topraklardaki görevli bütün kadıların onun idaresine verildiği belirtilmektedir. Bununla birlikte kādılkudatların sahip oldukları idarî yetkilerin dönemlere göre farklılık arzettiği ve özellikle kadı tayinlerinde başta halife olmak üzere vezirin de yetki sahibi olduğu ifade edilmelidir. ${ }^{71}$

69 İbnü'l-Cevzî, el-Muntazam, XVI, 227.

70 İbnü'l-Mûsalâyâ, Resâil, s. 434-37.

71 Kādılkudatlık kurumunun tarihi gelişimi, işleyişi ve ilgili literatür için bk. Göl, Abbâsîler Döneminde Kâdill-kudâtlık, s. 13-101; Özen, "Kādılkudât", s. 77-82. 
Abbâsî tarihinde devletin siyasî açıdan gücünü büyük ölçüde kaybettiği Büveyhî nüfuzu döneminde bile müessese olarak işlevini yitirmeyen kādılkudatlık kurumu ülkedeki bütün yargı sisteminin sorumluluğunu uhdesinde barındırmaya devam etmiştir. Nitekim Büveyhî nüfuzunun yoğun bir şekilde hissedildiği Mutî́-Lillâh (334-364/946-974) döneminde Ebü’lHasan Muhammed b. Sâlih el-Hâşimînin (ö. 364/975) kādılkudatlık makamına atandığına dair halife tarafından çıkarılan tevkīde Irak, Suriye ve Yemen'deki belli başlı şehirlerle buralara bağlı diğer yerleşim yerlerinin hukukî sorumluluğunun ve buralarda görevlendirilen kadıların denetim yetkisinin kādılkudata verildiği belirtilmektedir. ${ }^{72}$

Selçuklu nüfuzu dönemine gelindiğinde kādılkudatın tayiniyle ilgili İbnüll-Mûsalâyầnın kaleme almış olduğu bir tevkí` metni söz konusu kurumun V. (XI.) asırdaki işleyişine dair bazı ipuçları sunmaktadır. "Nüshatü ahdi kādi'l-kudât" ismiyle yazılan tevkīin hangi tarihte, kimin tarafından, kime yazıldığı bilinmemektedir. Mektubun ilk kısmında kādılkudatın ilim ve takva ehli, erdemli, basiretli, zâhit, kıvrak zekâlı ve mansıbının yükümlülüklerini yerine getirebilecek özelliklere eksiksiz bir şekilde sahip olması gerektiği belirtilmektedir. Diğer taraftan kādılkudatllğa tayin edilen kişinin başta Medînetüsselam (Bağdat) olmak üzere doğudaki ve batıdaki diğer şehirlerin kaza işlerine de tayin edildiği bildirilmektedir. Bu durum önceki dönemlerde olduğu gibi, bu dönemde de kādılkudatlık makamına atanan kişinin bütün yerleşim yerlerindeki yargı faaliyetlerinin denetimini ve buralara yapılacak kadı tayinlerini üstlenmiş olduğunu göstermektedir. Bununla irtibatlı olarak kādılkudattan güvenilir, iffetli ve liyakat sahibi kişileri kadı olarak görevlendirmesi istenmektedir. Mektupta halifenin kādılkudata yaptığı bazı nasihatlere de yer verilmektedir. Buna göre kādılkudatın insanların toplum içindeki konumlarına (güçlü, zayıf, zengin, fakir) bakmaksızın herkese karşı adaletli olması gerektiği vurgulanmakta, ayrıca kendisine bir dava geldiğinde önce Kur'an nassını ve Hz. Peygamber'in sünnetini dikkate alması, daha sonra icmâya, son olarak kendi içtihadına göre hükmetmesi gerektiği belirtilmektedir. Bu noktada kādılkudat olacak kişinin herhangi bir mezhebe mensup olması gerektiğine dair herhangi bir imada bulunulmaması dikkat çekmektedir.

Diğer taraftan bu nasihatler doğrultusunda idarî açıdan kādılkudatın emri altında çalışan bazı kişiler hakkında da bilgiler bulunmaktadır. Buna göre yerleşim yerlerinde görevli kadılar, yargı kararlarının altına isimleri yazılan şahitler, mahkeme kayıtlarını tutan kâtipler, yetimlerin ve vakıfların

72 İbnü'l-Cevzî, el-Muntazam, XIV, 222; Özen, “Kādılkudât”, s. 79. 
mallarının idaresinden sorumlu kişiler ve kamu düzeninin korunmasını sağlamakla görevli olan muhtesip bu görevlilerin başında gelmektedir. Halifenin nasihatlerinde bu görevlere getirilen kimselerin güvenilir ve âdil olmalarının yanında yükümlülüklerinin gereği olarak farklı bazı özelliklere de sahip olmaları gerektiği belirtilmektedir. Mesela kâtiplerin yazı sanatının ve şürût ilminin inceliklerini bilmesi gerekirken, muhtesibin ise fıkıh ilmine âşina olması gerekmektedir. ${ }^{73}$

\section{Divanlar}

İslam tarihinde ilk defa Hz. Ömer tarafından fethedilen toprakların idaresi ve buralardan elde edilen gelirlerin dağıtılması için kurulan divan teşkilatı, sonraki dönemlerde daha da gelişerek kendi içerisinde farklı dallara ayrılmıştır. Emevîler, bir taraftan Hulefâ-yi Râş̧idîn dönemindeki uygulamayı devam ettirirken, diğer taraftan devletin idarî ihtiyaçlarına binaen yeni divanlar da ihdas etmişlerdir. Abbâsîler ise özellikle II. (VIII.) asrın sonlarından itibaren mevcut divanların bir kısmını geliştirerek bir kısmına ise yenilerini ekleyerek ve her şeyden önemlisi resmî bir kurum olarak vezirlik müessesesini ihdas ederek devleti daha merkezî ve bürokratik bir yapıya kavuşturmuşlardır. Daha önceleri doğrudan halifeye bağlı olan divanların idaresi de artık vezirlerin uhdesine verilmiştir. III. (IX.) asrın başlarında büyük bir gelişme gösteren bu divanlar, vezirlerin idarî, hukukî, malî ve askerî alanlardaki yetkilerine ve sorumluluklarına göre şekillenmiştir. ${ }^{74}$

Büveyhîler'in Bağdat'ı ele geçirmesiyle siyasî ve idarî açıdan büyük bir zaafa uğrayan Abbâsî bürokrasisi neredeyse tamamen işlevini yitirmiş, buna bağlı olarak divanlar da âtıl hale gelmiştir. Bununla birlikte Büveyhî nüfuzunun ortadan kalkmasının hemen akabinde vezirlik kurumunun tekrar işlerlik kazanması divanlar açısından nispeten olumlu bir gelişme meydana getirmiş, ancak bu süreçte Selçuklu idaresinin etkisi yoğun bir şekilde hissedilmiştir. Selçuklu nüfuzunun hâkim olduğu dönemde işlevini devam ettirmeyi başaran Abbâsî bürokrasisinin (yani divanlar) yapısı ve işleyişiyle ilgili tarih kaynaklarında bazı ipuçlarına ulaşmak mümkün olsa da, Büveyhî nüfuzu öncesi dönemle kıyaslandığında bu bilgilerin nispeten az olduğu belirtilmelidir. Bu noktada İbnüll-Mûsalâyầnın kaleme aldığı mektupların Dîvânü'l-inşâ, Dîvânü't-terikât ve'l-haşriyye ve Dîvânü'l-cevâlî gibi divanlarla ilgili küçük de olsa bazı bilgiler vermesi önem arzetmektedir.

73 İbnü'l-Mûsalâyâ, Resâil, s. 388-97; Akle, "Dirâse”, s. 170-75.

74 Divanların Abbâsîler' in erken dönemindeki gelişimiyle ilgili geniş bilgi için bk. Aykaç, Abbasî Devletinin İlk Dönemi İdarî Teşkilâtında Dîvânlar, s. 39-172; Hançabay, Abbâsîler Döneminde Vezirlik, s. 58-76; Dûrî, “Divan”, s. 377-81. 


\section{a) Dîvânü'l-inşâ}

İslam tarihindeki ilk divanlardan biri olan Dîvânürr-resâil, Büveyhîler'den itibaren Dîvânü'l-inşâ ismiyle anılmaya başlanmıştır. Abbâsîler'in dışında Fâtımîler ve Selçuklular da bu divanı Dîvânü’l-inşâ şeklinde isimlendirmişlerdir. ${ }^{75}$ Söz konusu divan devletin resmî yazışmalarının takibini yapmak ve halife tarafından çıkarılan tevkīlerin metinlerini kaleme almakla yükümlüydü. Dîvânü'l-inşẩnın başında bulunan kişiye kâtibü’linşâ deniyordu ve bu kişi Abbâsî bürokrasisinde vezirden sonra en etkili kişilerden birisiydi. ${ }^{76}$ Nitekim Dîvanü'l-inşâ reisleri vezirliğe herhangi bir atamanın yapılmadığı bazı dönemlerde nâibülvezîr olarak görevlendirilmiş, bazan da halife adına vezirin görevleri arasında sayılan elçilik vazifesini üstlenmiştir.

İbnü'l-Mûsalâyâ uzun yıllar Dîvânü'l-inşẩnın reisliğini yapmış olmasına rağmen mektuplarında söz konusu divanın yapısı veya işleyişiyle ilgili doğrudan bir bilgi yer almamaktadır. Bununla birlikte henüz İslamiyet'i kabul etmeden önce Dîvânü’l-inşẩnın reisliğini yaptığ 1 sırada yazdığı mektuplarda zaman zaman ilgili âyet ve hadisleri kullanması hırıstiyan olan inşâ kâtiplerinin de bu konularda yetkin olarak yetiştirildiğini göstermektedir. Yazı üslubunun ve ifade biçimlerinin inceliklerine derinlemesine nüfuz etmesi beklenen inşâ kâtiplerinin, aynı zamanda güvenilir kimseler olmaları gerekiyordu. Bir başka ifade ile halifenin veya sultanın tercümanı konumunda olan bu kimseler, kendilerine muhtemelen şifahen söylenen halifenin emirlerini hem doğru bir şekilde anlama hem de bu emirleri halifenin şanına yakışır bir şekilde edebî bir dille yazıya dökme sorumluluğunu taşıyorlardı. Bu noktada tevkǐ metinlerinde halifenin emirlerinin yanı sıra dinî ifadelerin de doğru ve yerinde kullanılması konusunda İbnü'l-Mûsalâyâ örneğinde olduğu gibi gayrimüslim kâtiplerin de maharet kespettikleri anlaşılmaktadır. ${ }^{77}$

\section{b) Dîvânü't-terikâti'l-haşriyye}

Dîvânü't-terikâti'l-haşriyye arkasında herhangi bir vâris veya asabe ${ }^{78}$ b1rakmadan vefat eden kişinin mallarıyla veya bu malların vârislere dağıtıldıktan sonra asabesi olmadığı için geriye kalan kısmılla ilgilenmek üzere

75 Dûrî, “Divan”, s. 380.

76 Akle, "Dirâse", s. 164.

77 Bazı örnekler için bk. İbnü'l-Mûsalâyâ, Resâil, s. 233, 236-37, 259-61 264-65, 279, 288-301. 78 İslam hukukunda miras bırakana doğrudan veya erkek vasitasıyla bağlı bulunan mirasçılar için kullanılan fıkıh terimi (geniş bilgi için bk. Karaman, "Asabe", s. 452-53). 
kurulmuştur. ${ }^{79}$ Kalkaşendî bu divanın Mısır bölgesinde ve Mısır dışındaki bölgelerde görev yapan iki şubesinin olduğunu söylemektedir. ${ }^{80}$

Sıbt İbnü'l-Cevzînin aktardığı bir kayıtta söz konusu mallarla ilgili Selçuklu nüfuzu döneminde Bağdat'ta kısmen benzer bir uygulamanın olduğu anlaşılmaktadır. Şöyle ki, Kāim-Biemrillâh’n halifeliği zamanında Bağdat'ta bir kız çocuğu olan bir adam geride 3000 dinar bırakarak vefat etti. Bunun üzerine Selçuklular’ın Irak valisi Reîsülırakeyn’e (Amîdülırâk Ebû Ahmed en-Nihâvendî) adamın miras olarak bıraktığı bu paranın yarısının sultanın hakkı olduğu söylendi. Bunun üzerine vali, sultanın (yani halife) "bu şekilde vefat eden kişinin geride bıraktığı malları (el-mevârisü’lhaşriyye) onun yakınlarına verin" emri uyarınca babasından kalan 3000 dinarın (tamamı) kıza verilmesini emretti. Yine aynı dönemde halifenin hareminde yaşayan ve bir kızı olan bir kadın geride boş bir dolap (veya sandık) bıraktı. Bu şekilde miras kalan malların idaresinden sorumlu olan İbn Attâr, halifenin emrine muhalif davranarak bu dolabı 1,5 dinara satt1, kıza 15 kırat verdi, kalanını ise alıkoydu. Ancak onun bu tavrı insanlar tarafından hoş karşılanmadı. ${ }^{81}$

İbnü'l-Mûsalâyẩnın mektuplarında benzer uygulamaların sonraki dönemlerde de devam ettiğini gösteren bazı ipuçları bulunmaktadır. Buna göre Muktedî-Biemrillâh, Amîdülırâk Ebü’l-Feth b. Ebü'l-Leys'in birtakım haksız uygulamalarından duyduğu rahatsızlığı iletmek üzere Ebû İshak eş-Şîrâzîyi (ö. 476/1083) elçi olarak Melikşah ve veziri Nizâmülmülk'e gönderdi. ${ }^{82}$ "Nüshatü'l-kitâbi ilâ Nizâmilmülk" adıyla yazılan mektupta Amîdülırâkın gerek tüccar ve zanaat ehlinden gerekse çiftçilerden aldığı haksız vergilerden bahsedilirken, onun ayrıca ölen kişinin miras olarak bıraktığı mallardan da vergi aldığı bildirilmiştir. ${ }^{83}$

Tarih kaynaklarında yer alan bilgiler birlikte düşünüldügünde yukarıda zikredildiği şekliyle miras olarak bırakılan malların idaresi için bir divanın kurulduğu anlaşılmaktadır. Ancak bu divanın görevi aslında söz konusu mallardan vergi almak değil, hilafet makamının da muvafakatiyle bu malları ölen kişinin akrabaları arasında yeniden dağıtmaktır. Bununla birlikte söz konusu divanın başındaki bazı kişilerin zaman zaman bu mallarla ilgili şahsî birtakım yanlış tasarruflarda bulundukları anlaşılmaktadır.

79 Kalkaşendî, Subhu'l-a ş̧â, IV, 33.

8o Kalkaşendî, Subhu'l-a'şâ, III, 464.

81 Sıbt İbnü'l-Cevzî, Mirâtüz-zamân (Sevim), s. 83.

82 İbnül-Esîr, el-Kâmil, X, 125-26; Bündârî, Zübdetün-Nusra, s. 75.

83 İbnül-Mûsalâyâ, Resâil, s. 208-11, 211, dn. 3 . 


\section{c) Dîvânü'l-cevâlî}

Cevâlî, "iclâ edilen" (sürülen) anlamına gelen câliye kelimesinin çoğulu olup, İslam tarihinde ilk defa Hz. Ömer'in Hayber ve çevresindeki yahudilerle Necran'da ikamet eden hıristiyanları Arap yarımadasından çıkarması sebebiyle bu kimseler için kullanılmıştır. Ancak zamanla gayrimüslimleri (ehl-i zimme) ve onlardan (kadın, yaşlı, çocuk ve fakir olanlarının dışında) yılda bir defa alınan cizyeyi ifade etmek üzere kullanılmaya başlanmıştır. $\mathrm{Bu}$ cizyeleri toplamak ve elde edilen geliri idare etmek için farklı dönemlerde ve coğrafyalarda Dîvânüll-cevâlî, Mukātaâtü'l-cevâlî (cevâlî mukātaası) ve Nezâretü’l-cevâlî (cevâlî nâzırlığı) adıyla müesseseler ihdas edilmiştir. Böylece asıl anlamını kaybeden cevâlî kelimesi, İslam toplumunda yaşayan gayrimüslimlerin gördükleri himayenin maddi karşıllğı olarak ödedikleri cizye vergisi ve bu verginin idaresi anlamını kazanmıştır. ${ }^{84}$

Sıbt İbnül-Cevzînin verdiği bilgiye göre 453 (1061) yllında Selçuklular’n Irak valisi Reîsülırâkeyn’in Bağdat'taki bazı faaliyetlerinden bahsederken onun yıllık geliri 1500 dinar civarında olduğu söylenen Dîvânü'l-cevâlî gelirlerine el koyduğu belirtilmektedir. ${ }^{85}$ Diğer taraftan İbnüll-Mûsalâyâ tarafından "Nüshatü ahdin ketebehu'l-Kâim li sâhibi'l-Endelüs" başlı̆̆ıla kaleme alınan ve Kāim-Biemrillâh adına Endülüs emîrlerinden birine ${ }^{86}$ gönderilen

84 Geniş bilgi için bk. Seyyid, “Cevâlî”, s. 436-37.

85 Sibt İbnü’l-Cevzî, Mirâtü̈z-zamân (Sevim), s. 87.

86 Mektupta Endülüs emîrinin kim olduğuna dair herhangi bir bilgi bulunmamaktadır. Ancak aynı mektubu eserinde zikreden Kalkaşendî, söz konusu emîrin Murâbıtlar'in hükümdarlarından Yûsuf b. Tâşfîn (465-50o/1073-1106) olduğunu belirtmektedir (bk. Kalkaşendî, Subhu'l-a ş̧â, X, 31). Akle'ye göre ise bu mektup 463 (1070) yılı civarında yazılmış olmalı, çünkü Endülüs halkının Kāim-Biemrillâh'a biat ettiğini haber veren mektuba cevaben bir mektup gönderen halife, Endülüs emîrinden halkı hac ibadetine teşvik etmesini istemektedir. Sözlerinin devamında İbnü'l-Esîr'i (el-Kâmil, X, 61) kaynak göstererek (uzun bir süredir Fâtımîler'in hâkimiyeti altında bulunan) Mekke'de hutbelerin 462 (1069) yılında Kāim-Biemrillâh adına okunmaya başlandığını belirten Akle, bundan dolayı söz konusu mektubun ancak bu tarihten sonra Endülüs emîrine gönderilmiş olması gerektiğini söylemektedir. Akle ayrıca Yûsuf b. Tâş̧în'in vefatına kadar ismen Ebû Bekir b. Ömer el-Lemtûnîye tâbi olduğunu, dolayısıyla bu mektubun Yûsuf b. Tâşfîn’e hitaben gönderilmesinin mümkün olmadığını ileri sürmektedir (bk. İbnü’l-Mûsalâyâ, Resâil, s. 286, dn. 1). Kalkaşendînin verdiği bilgi ve Akle’nin yorumları dikkate alındığında ismi meçhul emîrin Yûsuf b. Taşfîn olması daha muhtemel gibi görünmektedir. Zira Akle’nin söylediğinin aksine, Ebû Bekir b. Ömer, Sudan bölgesine yönelik düzenlediği sefer sonunda Yûsuf b. Tâş̧în'in kalabalık bir orduyla kendisini karşıladığını görünce yetkilerinden feragat ederek tahtını Yûsuf b. Tâş̧îne bırakmıştır. Yûsuf da Murâbıtlar’ın ileri gelenlerinden biat alarak Merâkeş'i Murâbıtlar’ın başşehri yapmış (465/1073), bu tarihten sonra da Murâbıtlar'ın hükümdarı olmuştur (geniş bilgi için bk. Özdemir, "Yûsuf b. Tâş̧în”, s. 30-31). Dolayısıyla Yûsuf b. Tâş̧în’in ömrünün sonuna kadar Ebû Bekir b. Ömer'e tâbi olmadığı ve yine Yûsuf b. Tâş̧în'in hükümdar olmasıyla Mekke'de hutbelerin Abbâsî halifesi adına okunmasının aynı döneme denk geldiği anlaşılmaktadır. 
mektupta Dîvânü'l-harâc, Dîvânüd-diyấ', Dîvânül-aşâr, Dîvânü'l-cehbeze, Dîvânü’s-sadakāt ve Dîvânü'l-cevâlî âmillerinin liyakat sahibi, güvenilir, iffetli kimselerden seçilmesi istenmiştir. Ayrıca ehl-i zimmenin kadın, çocuk, yaşlı, fakir ve ruhbanları dışındakilerinden güçleri oranında her yıl cizye alınması emredilmiștir. ${ }^{87}$

\section{Sonuç}

İbnü'l-Mûsalâyẩnın babası Hasan b. Vehb, ailenin Abbâsî idarî tarihindeki muhtemelen ilk temsilcisi olup Kāim-Biemrillâh döneminde Dîvânü'linşẩda kâtiplik yapmıştır. Babası gibi kendisi de kâtiplik mesleğini seçen İbnü'l-Mûsalâyâ yirmili yaşlardayken Dîvânü'l-inşẩda kâtip olarak çalışmaya başlamış ve 443 (1051) yılından daha önceki bir tarihte söz konusu divanın reisliğine atanmıştır. Bu görevini elli yıldan daha uzun bir süre devam ettirmiştir. İbnü’l-Mûsalâyânın hayatının dönüm noktalarından biri kırk yılı aşan bir süre hırıstiyan olarak Dîvânü'l-inşẩnın reisliğini yaptıktan sonra Muktedî-Biemrillâh’nn halifeliği döneminde İslamiyet'i kabul etmesidir. Bazı araştırmacılar onun Kāim-Biemrillâh döneminde müslüman olduğunu söylese de, bu iddianın ilgili kaynaklardaki bilgilerle teyit edilmesi mümkün değildir. Büveyhîler'den Selçuklular'a geçiş sürecinde Dîvânü'l-inşâ reisliğinin yanı sıra üç defa nâibülvezirlik yapan İbnü'l-Mûsalâyâ, ahlakî meziyetleri ve mesleğindeki başarısı sebebiyle başta Abbbâsî halifeleri olmak üzere Selçuklu sultanları ve vezirlerinin nezdinde büyük bir itibar elde etmiştir. Ömrünün sonlarına doğru görme yetisini kaybeden İbnü'l-Mûsalâyâ, muhtemelen hiç evlenmediği için kaynaklarda aile fertleriyle ilgili herhangi bir bilgi bulunmamaktadır.

İbnüll-Mûsalâyẩnın farklı konularda kaleme aldığı resmî ve şahsî mektupların ikinci bölümü ve muhtemelen küçük bir kısmı 603 (1207) yılında ismi bilinmeyen bir müstensih tarafından bir araya getirilmiş ve zamanımıza kadar ulaşmıştır. Sayıları altmış altııı bulan bu mektupların büyük bir kısmı Selçuklu devlet adamlarına yazıldığı için Abbâsîler' in Selçuklular ile ilişkilerine dair birinci elden kaynak özelliği taşımaktadır. Bunların dışında vezirlik makamına ve kādılkudatlığa yapılan atamalarla ilgili üç tane tevkīi metnini ihtiva etmesi ve bazı divanlar hakkında küçük de olsa bilgiler vermesi söz konusu mektupların Abbâsî idarî tarihi açısından da önemli birer kaynak olduğunu göstermektedir.

87 İbnül-Mûsalâyâ, Resâil, s. 297-98. 
Tarih kaynaklarında vezirliğe yapılan atamalarla ilgili halifenin tevkīi çıkardığından bahsedilmekle birlikte, çoğu zaman söz konusu tevkīlerin gerek şeklî özellikleri gerekse muhtevası hakkında herhangi bir bilgi verilmemektedir. İbnü’l-Mûsalâyânın kaleme aldığı sekiz mektuptan iki tanesi Kāim-Biemrillâh döneminde vezirlik yapan İbn Dârest ve Fahrüddevle’nin bu makama atandıklarına dair halifenin çıkardığı tevkīi metinlerini içermektedir. Birbirinden bazı farklılıklarla ayrılan bu metinlerden birincisinde önce halifeyi öven açıklamalara yer verilirken, diğeri uzunca bir hamdele (Allah'a hamd) ve salvele (Hz. Peygamber'e salavat) kısmıla başlamaktadır. Daha sonra her ikisinde de vezirliğe namzet olacak kişinin sahip olması gereken özelliklerden bahsedilmekte, son kısımda ise halife tarafından vezire yapılan nasihatlerden söz edilmektedir. Bunların dışında her iki vezirin göreve atanması sırasında mevcut siyasî şartlar da dile getirilmektedir. Yine bu iki vezirin tayini münasebetiyle Selçuklu sultanı ve vezirine gönderilen diğer üç resmî mektupta da siyasî açıdan benzer hususlara değinilmektedir. Bu noktada iki farklı türde kaleme alınan bu tevkī‘ metinleri hem Selçuklu nüfuzunun hâkim olduğu dönemde Abbâsîler'deki vezirlik müessesesinin tarihi gelişimine 1şık tutmakta hem de tarih kaynaklarında yer alan bilgilerle birlikte dönemin siyasî panoramasını daha doğru bir şekilde sunmaya yardımcı olmaktadır.

Vezirlik kurumunun dışında kādılkudatllğga yapılan atamayla ilgili çıkarılan tevkī metninde kādılkudat olarak görev yapacak kişilerde aranan şartlar, kādılkudatın yetki ve sorumlulukları ve emrinde çalışan kimseler hakkında bilgiler yer almaktadır. Bunun yanında yine kādılkudatın Kur'an, sünnet ve icmâdan sonra kendi içtihadına göre karar verirken yargılama usulüne dair uyması gereken kurullarla ilgili bazı ipuçlarına ulaşmak da mümkündür. Bu noktada kādılkudatın kendi içtihadı söz konusu olduğunda herhangi bir mezhebin reyine itibar edip etmemesine dair bir imada bulunulmamış olması ayrıca dikkat çeken bir husus olarak zikredilmelidir. Bu durum farklı mezheplere mensup kadıların bu göreve tayin edildiği anlamına gelebilirken, bir kādılkudatın hüküm verirken kendisini bir mezhebin görüşüyle sınırlandırmaması gerektiğine dair bir işaret olarak da düşünülebilir.

Kādılkudatlık müessesine nazaran hakkında daha az bilginin yer aldığı bir diğer kurum divanlardır. İbnü’l-Mûsalâyâ uzun yıllar Dîvânü'l-inşẩda görev yapmasına rağmen mektuplarında bu divanın işleyişine dair doğrudan bir bilgi yer almamaktadır. Bununla birlikte ömrünün büyük bir kısmını hıristiyan olarak geçirmesine rağmen onun Kur'an ve hadis metinlerini doğru ve anlaşılabilir bir şekilde yazarken gösterdiği titizlik ve başarı, gayrimüslim kâtiplerin müslüman olan meslektaşları gibi bu konularda iyi yetiştirildiğini 
göstermektedir. Ayrıca Dîvânü't-terikâti'l-haşriyye ve Dîvânü’l-cevâlî gibi bazı divanların varlığına dair mektuplarda yer alan ipuçları Abbâsî idarî tarihi hakkında nispeten az bilginin bulunduğu V. (XI.) asır açısından da bu mektupların önemine işaret etmektedir.

\section{Bibliyografya}

Akle, İsâm Mustafa Abdülhâdî, "Dirâse", İbnü'l-Mûsalâyâ, Resâilü Emîniddevle, nşr. İsâm Mustafa Abdülhâdî Akle içinde, s. 31-183.

Aykaç, Mehmet, Abbasî Devletỉnin İlk Dönemi İdarî Teşkilâtında Dîvânlar: 132-232/750847, Ankara: Türk Tarih Kurumu, 1997.

Azzâm, Subhî Mahmûd, el-Vizâretü'l-Abbâsiyye (447-656/1055-1258) (doktora tezi), Ürdün Üniversitesi, Amman, 2000.

Bündârî, Zübdetünn-Nusra ve nuhbetü'l-usra: Irak ve Horasan Selçukluları Tarihi, trc. Kıvameddin Burslan, Ankara: Türk Tarih Kurumu, 1999.

Dayf, Şevkī, Târîhu'l-edebil-Arabî: Asrü̉d-düvel ve'l-imârât (el-Cezîretü'l-Arabiyye - el-Irâk - Îrân), Kahire: Dârü'l-maârif, 1980.

Dûrî, Abdülaziz, “Divan”, DİA, 1994, IX, 377-81.

Göl, Yavuz Selim, Abbâsîler Döneminde Kâdil'-kudâtllk (doktora tezi), Necmettin Erbakan Üniversitesi, Konya, 2018.

Hançabay, Halil İbrahim, Abbâsîler Döneminde Vezirlik (295-530/908-1136), İstanbul: Klasik Yayınları, 2017.

Hüseynî, Ali b. Nâsır [?], Ahbârü̉d-devletỉs-Selcûkyyye, trc. Necati Lugal, Ankara: Türk Tarih Kurumu, 1999.

İbn Haldûn, Târîh, nşr. Halîl Şehhâde, I-VIII, Beyrut: Dârüll-fikr, 1421/2000.

İbn Hallikân, Vefeyâtü'l-a'yân, nşr. İhsan Abbas, I-VIII, Beyrut: Dâru sâdır, ts.

İbn Miskeveyh, Tecâribü'l-ümem, nşr. H. F. Amedroz, I-VII, Oxford 1920-21.

İbnü'l-Adîm, Bugyetü't-taleb fì târîhi Haleb, nşr. Süheyl Zekkâr, I-XII, Beyrut: Dârü'l-fikr, ts.

İbnü'l-Cevzî, Ebü'l-Ferec, el-Muntazam fî târîhi'l-mülûk ve'l-ümem, nşr. M. Abdülkādir Atâ

- Mustafa Abdülkādir Atâ, I-XVIII, Beyrut: Dârül-kütübi'l-ilmiyye, 1412/1992.

İbnü’d-Dimyâtî, Ahmed b. Aybek, el-Müstefâd min Zeyli Târîhi Bağdâd, nşr. Mustafa Abdülkādir Ata, Beyrut: Dârü'l-kütübi'l-ilmiyye, 1417/1997.

İbnü'l-Esîr, İzzeddin, el-Kâmil fìt-târîh, nşr. C. J. Tonberg, I-XIII, Beyrut: Dâru sâdır - Dâru Beyrut, 1385-86/1965-66.

İbnü’l-Mûsalâyâ, Resâilü Emîniddevle, nşr. İsâm Mustafa Abdülhâdî Akle, Ayn: Merkezü Zâyed li't-türâs ve't-târîh, 1424/2003.

İmâdüddin el-İ́sahânî, Harîdetül'-kasr ve cerîdetül'-asr: el-Kısmü'l-Irâkī, nşr. M. Behçet elEserî - Cemîl Saîd, I-III, Bağdat: Matbaatü mecmai'l-ilmî el-Irâkī, 1375-84/1955-64. 
Kalkaşendî, Subhu'l-a ş̧â, I-XIV, Kahire: el-Matbaatü'l-emîriyye, 1334-40/1915-22.

Karaman, Hayreddin, “Asabe”, DİA, 1991, III, 452-53.

Kılavuz, Ahmet Saim, “Giyâr”, DİA, 1996, XIV, 59.

Mârî b. Süleyman, Ahbâru Fetâriketi kürsiyyil-meşrik, nşr. Henricus Gismondi, Roma: F. de Luigi, 1899.

Nüveyrî, Ahmed b. Abdülvehhâb, Nihâyetül-ereb fî fünûni'l-edeb, I- XXIII, Beyrut: Dârü’lkütübi'l-ilmiyye, 1424/2004.

Özaydın, Abdülkerim, "Mezyedîler”, DİA, 2004, XXIX, 550-51.

Özdemir, Mehmet, “Yûsuf b. Tâş̧în”, DİA, 2013, XLIV, 30-32.

Özen, Şükrü, “Kādılkudât”, DİA, 2001, XXIV, 77-82.

Öztürk, Levent, Asr-ı Saadetten Haçlı Seferlerine Kadar İslâm Toplumunda Hıristiyanlar, İstanbul: İz Yayıncılık, 1998.

Seyyid, Seyyid Muhammed, “Cevâlî”, DİA, 1993, VII, 436-37.

Sıbt İbnü'l-Cevzî, Mirâtü̈z-zamân, VIII/1, Haydarâbâd: Dâiretü’l-maârifi'l-Osmâniyye, 1370/1951.

Sıbt İbnü’l-Cevzî, Mirâtü̉z-zamân, nşr. Ali Sevim, Ankara: Ankara Üniversitesi Dil ve Tarih Coğrafya Fakültesi Yayınları, 1968.

Sübkî, Tâceddin, Tabakātüşs-Şâfiizyeti'l-kübrâ, nşr. Mahmûd M. et-Tanâhî - Abdülfettâh M. el-Hulv, I-X, Kahire: Dâru ihyâi'l-kütübi'l-Arabiyye 1383-96/ I964-76.

Yâkūt el-Hamevî, Mu'cemü'l-üdebâ', I-XX, Beyrut: Dârü'l-fikr, 1400/1980.

Zehebî, Siyeru a 'lâmi’n-nübelâ', nşr. Şuayb el-Arnaût v.dğr., I-XXV, Beyrut: Müessesetü'rrisâle 1402-1409/1982-88.

Zehebî, Târîhu'l-İslâm: sene 491-500, nşr. Ömer Abdüsselâm Tedmürî, Beyrut: Dârü’lkitâbi'l-Arabî, 1415/1994. 


\section{An Important Source for Abbasid Administrative History: Amin al-Dawla Ibn al- Mūṣalāyā (d. 497/1104) and His Official and Personal Letters}

Abu Sa 'd 'Alā' b. Ḥasan, also known in sources as Ibn al-Mūșalāyā out of respect for his Christian grandfather, was born on 6 Shawwāl 412 (13 January 1022) in Karkh quarter of Baghdad. Ibn al-Mūșalāyā’s father Hasan b. Wahb was the first family member employed in the Abbasid administration, serving as a scribe in the chancery department during the caliphate of al-Qẩim (r. 1031-1075). Like his father, Ibn al-Mūșalāyā chose a scribal career for himself and began working for the chancery department in his twenties. He was appointed head of the chancery sometime before 443/1051 and he remained in this position for more than fifty years. One of the turning points in his life was his conversion to Islam during the reign of al-Muqtadi, after having served as head of the chancery more than forty years. In addition to his role in the chancery, he also served as vice-vizier three times during a period of transitional rule from the Buyids to the Seljuks. He acquired considerable esteem among the Abbasid caliphs and Seljuk sultans for his ethical virtues and success in his job. Ibn al-Mūṣalāyā lost his sight at an old age. Likely due to the fact that he never married, no information about his family members exists in the sources.

From the letters of Ibn al-Mūṣalāyā, only the second part and most probably only a small section is extant. These letters were collected by an anonymous scribe on 8 Jumādā al-ākhir 603 (10 January 1207), with the only surviving copy being kept in the Tunisian National Library. 'Ișām 'Aqla prepared a critical edition of this letter, titled, al-Khiläfa al-'Abbāsiyya fì daw'i rasā'il Amīn al-dawla: Dirāsa wa al-taḥīq in 1997 as his Ph.D. dissertation in Jordan University; it was published with the title Rasā'il Amìn al-dawla Ibn al-Mūṣalāyā in 2003.

The purpose of this article is to draw researchers' attention to the letters of Ibn alMūṣalāyā, which constitute rare examples of research into Abbasid administrative history. The article consists of two parts. The first part outlines the life of Ibn alMūṣalāyā. The second part, based on the contents of the letters, examines certain Abbasid institutions such as the vizierate, the chief-judgeship and certain bureaus during the fifth/eleventh century.

The letters, made up of sixty six texts, were written from 451 (1059) to 491 (1097). Ibn al-Mūṣalāyā addressed three of them personally to the Seljuk viziers 'Amīd al-Mulk al-Kundurī and Niẓām al-Mulk, and a prominent Christian physician Mútamid al-dawla Abū al-Faraj Yahyā b. Sa ìd b. Tilmīdh (d. 512/1118). Further, he addressed seven of them to Abbasid Caliph al-Muqtadī (d. 487/1094), one to al-Mustazhir (d. 512/1118), and forty-seven to al-Qāim (d. 467/1075). We could not verify the addressee(s) of the remaining eight letters. Most of the letters (27 of them) penned on behalf of the Abbasid caliphs were addressed to Seljuk sultans such as Tughrul Beg, Alp Arslan, Malikshah, etc.

Two letters of Ibn al-Mūṣalāyā are particularly salient, as they include chancery texts about two individuals, Ibn Dārast and Fakhr al-dawla Muhammad b. Jahīr, who were ultimately appointed to the post of vizierate. Although sources mention that appointments to vizierate were usually accompanied by chancery documents 
issued under the caliph's name, they provide no detail for the format or the content of these documents. The first of these letters begins with panegyric phrases for the caliph whereas the second does so by thanking God and relaying greetings to the Prophet. Both then talk about the necessary qualifications of the candidate viziers and then end with sections that include caliphal advice to the viziers. In addition, both letters talk about political conditions at the time of the each vizierial appointment, respectively. Furthermore, for the same occasion of these appointments, three other letters addressed to the Seljuk sultan and vizier also address similar political realities. Therefore, these chancery documents, penned in two different genres, shed light on the Abbasid vizierate at a time when the Seljukid influence was dominant. They also address political developments, providing historians with political insight and context.

The letter on the chief-judgeship outlines the necessary qualifications of a chiefjudge, his authority and responsibilities, and the people working under his supervision. It then details the adjudication process while a chief-judge is deciding on a matter by consulting the Quran, Prophetic tradition, communal consensus and his own personal view. It is worth noting here that the letter does not specifically advise adopting a particular school's position, should a chief-judge consult to his own view. That could mean that judges from different schools were eligible for the appointment as chief-judge, and that a chief-judge should not limit himself to his school's adopted positions on specific matters.

Bureaus (dīwāns) were of another type of institution about which we find limited information. Although Ibn al-Mūṣalāyā worked long in the Chancery Bureau (Dìwàn al-inshä), he offered very little content directly related to this bureau. However, although he lived most of his life as Christian, his attention to Quranic verses and prophetic traditional texts shows that non-Muslim scribes were well educated in these areas, like their Muslim colleagues. In addition, these letters mention the existence of bureaus such as Dìwān al-tarikāt al-hashriyya and Dìwān al-jawāli, revealing the importance of these institutional structures to the Abbasid administration.

Keywords: Abbasids, Seljuks, Ibn al-Mūṣalāyā, vizierate, Chief-Judge, administrative bureaus, dīwān. 